\title{
Promoting Aid Effectiveness from the Bottom Up with IC'Ts
}

\section{BY CAROLINE FIGUÈRES, DENISE SENMARTIN AND HILDE EUGELINK}

ISABEL, FROM CAMILLAYA in the Inquisivi region of western Bolivia, has never heard of aid effectiveness, but she knows what has made her become a more successful entrepreneur. For two years now, she has been using a camera to record the activities of the Integral Association of Producers, a farmers' group which cultivates natural medicines, honey, and other products as an alternative to timber. Making videos and PowerPoint presentations are part of the Information and Communication Technology (ICT) for the Exchange of Farmer Experiences in Ecological Agriculture project, managed by the AGRECOL Andes Foundation and supported by the International Institute for Communication and Development (IICD). In Isabel's words, "the computer and digital camera work with concrete information like words, number, images, sounds...They are tools that help us collect our grandparents' experiences and share and exchange our knowledge." Using these tools enables her to work more efficiently and effectively and allows her to exchange lessons learned with other producers about issues such as quality improvement, commercialization, and the challenges of working with the community.

How does this reality, experienced by local development organizations working on the ground, relate to the overall aid effectiveness mandate and the Accra Agenda for Action? Why does incorporating ICT components in development programs and projects provide an opportunity for the aid effectiveness agenda? And what can a project in a rural area tell us about this?

Information and communication technologies (ICTs) is a blanket term for all technologies that collect, access and disseminate information. They include both traditional (radio and TV) and mod- ern technologies (mobile phones, video, computers, the Internet). Experiences on the ground tell us that when ICT components are incorporated into livelihoods, health, education, gender, governance and environment projects, the possibilities and results are compelling.

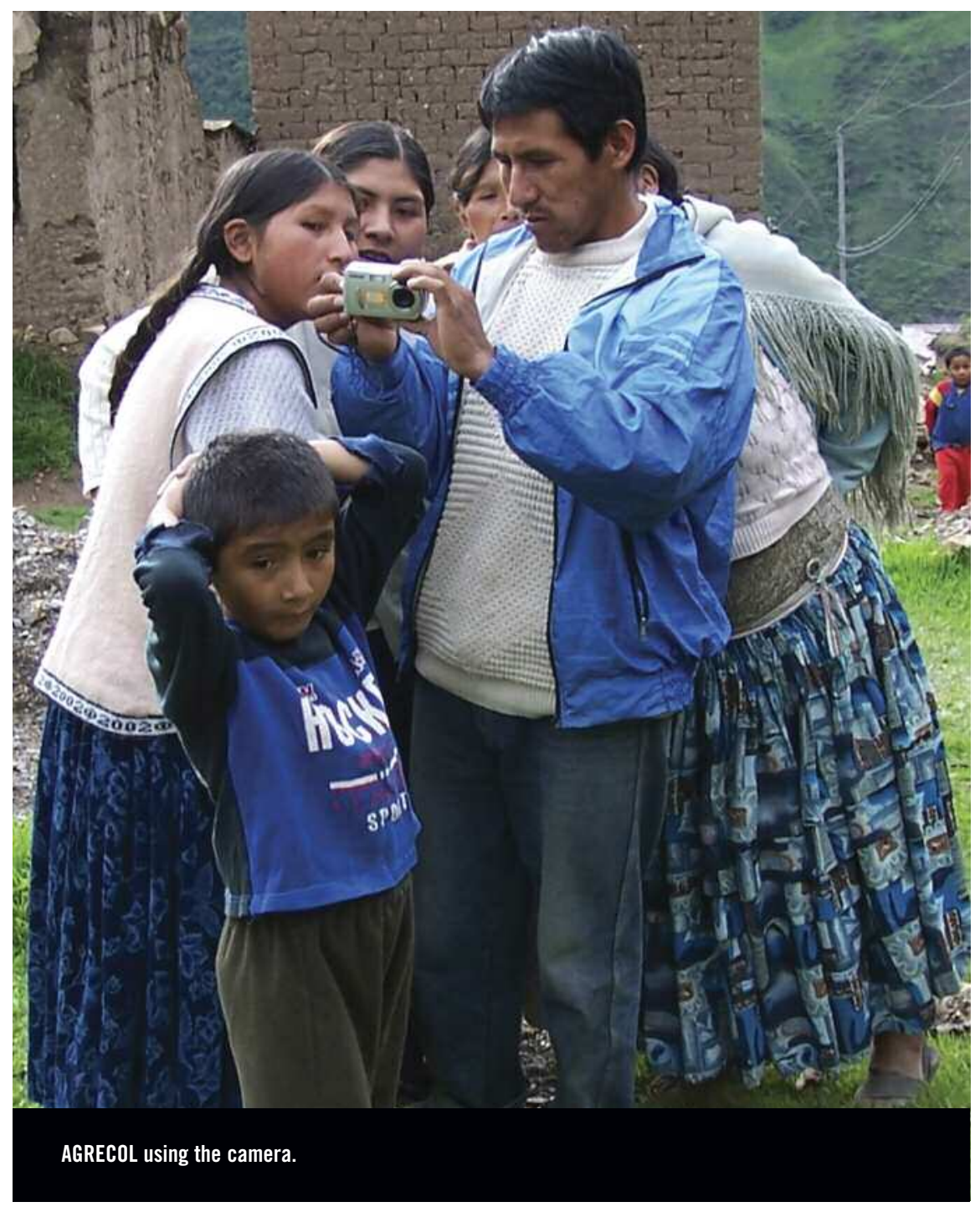


Monitoring and evaluation data show that, in 2007, about 50 percent of AGRECOL's above mentioned project participants noticed a direct improvement in their income of 10 percent as a direct result of taking part in it. ${ }^{2}$ About 60 percent reported a greater awareness of the benefits of ICT and felt empowered to negotiate with intermediaries. The project is also having an impact on the community, the region and beyond as their traditional knowledge, which has now been systematized, is being incorporated in regional agricultural strategies and educational materials in schools. ${ }^{3}$

In general, the ICT and livelihood opportunities projects supported by IICD show improved revenues, and better efficiency, cooperation and productivity. ICTs allow skills to be developed and resources to be mobilized in such a way that, once adopted and incorporated in personal and professional activities, the impact will continue even after aid is over.

\section{ICT's as development driving tools}

RECENT STUDIES stress the importance of ICTs in boosting economic development. A comprehensive international study investigating the correlation between changes in ICT investment levels and GDP growth across different regions shows that as a result of ICT investments, the economic growth in Sub-Saharan Africa increased about ten percent in the period 1995-2003 compared to the period $1989^{-1995}{ }^{4}$ Over the past decade, ICT has proven to be a key factor for improvements in different environments (public and private sectors, individuals, and groups) supporting new processes, and increasing efficiency, transparency and participation.

ICT has also had an instant impact on the quality of life, in a concrete and direct way. From the radio to mobile phones, ICT makes the intersection and levelling of the global and local spheres possible by democratizing information flows. ICT leverages knowledge, which drives competitiveness and shapes economic growth patterns. ${ }^{5}$ ICT is one of the four pillars of a knowledge economy, together with a sound economic and institutional regime, strong education base, and innovation systems.

The Third High Level Forum on Aid Effectiveness in Accra made clear that even though progress has been made on the 2005 Paris Declaration targets, donors and partner governments are still lagging behind. Areas for improvement include: predictability, ownership, country systems, conditionality, untying, aid fragmentation, partnerships and transparency. Many aspects of these issues are related to information flows and management, cooperation, and the localization of development efforts. This means that ICT has a key role to play in aid effectiveness.

Ownership, alignment and harmonization, and monitoring for results and transparency are areas that can improve considerably with ICT.

\section{Appropriating processes: ICTs for ownership}

Ownership and country systems mean that countries set their own development objectives and are held responsible not only for the results, but also for the process. Ownership and appropriation of development strategies involve incorpo- rating criteria and new skills acquired when the program or project is implemented. At the project level, this is perceived through the awareness of the stakeholders that comes about as a gradual and enriching experience in the process of readapting the local realities and practices based on new knowledge. This ownership process applies to strategies at both local and national levels.

Incorporating ICT in development programs and projects provides both the opportunity and the challenge to explore, find and define new ways to do what is already being done, but more effectively and efficiently. Implementing ICT solutions may be seen as a technical solution introduced by an outsider who installs a computer to automate manual activities. In fact, it has more fundamental implications. In practice, implementing ICT in any thematic area, from an agriculture information system to a telemedicine project, involves rethinking the working processes and roles in a local organization which, in turn, leads to changes in management, information flows, and communication patterns.

In the case of IICD's work, re-defining processes has been tackled by establishing national round tables where the stakeholders involved in a thematic development area come together to identify how ICT can help them, and together identify solutions based on their concrete needs and demands. When the projects start, all the major stakeholders are key partners responsible for the strategy and the results.

Alignment is another important aspect in which ICTs are making a difference. For governments, the implementation of ICTs is fostering more effective information management systems and wider communication among key stakeholders, allowing further alignment of criteria and priorities that are reflected in national strategies. At the global level, platforms like the Accessible Information on Development Activities (AiDA), hosted by the Development Gateway Foundation, ${ }^{6}$ provide access to a full picture of development activities around the world grouped by country, sector, donor, and harmonizing data.

As information and communication tools continue to spread, we will see an increment in innovative uses. For example, mobile phones are now used for health, business and education purposes. As these technologies can be used by anyone without being an expert, people are showing ownership in its most simple definition, producing changes in concrete situations that reshape their lives.

\section{Monitoring for results: ICTs for transparency}

Transparency is another area highlighted in the Accra Agenda for Action that needs to be improved with better assessments, results monitoring, and broader parliamentary and citizen engagement.

ICTs can support monitoring and evaluation for results through the implementation of national aid management platforms, procurement, customs, and financial systems. At the same time, ICTs provide the means through which that information can be disseminated and distributed for public access. ${ }^{7}$

One particular challenge is how to involve parliamentarians and citizens in the monitoring process. Some experiences at the local level indicate how ICT can make this possible. For instance, 
THE INTERNATIONAL INSTITUTE

FOR COMMUNICATION AND DEVELOPMENT

The International Institute for Communication and

Development (IICD) creates practical and sustainable solutions that connect people and enable them to benefit from ICT. Our approach includes linking local, national and international organisations as well as formulating and implementing ICTsupported development policies and projects. As an

independent not-for-profit foundation, we work with partners

from the public, private and not-for profit sectors.

We are currently involved in Bolivia, Burkina Faso,

Ecuador, Ghana, Jamaica, Mali, Tanzania, Uganda and Zambia

in the following sectors: education, governance, health,

livelihoods (mainly agriculture), and the environment. So far,

138 projects have been supported by IICD, out of which 30

percent are now continuing independently and 11 percent

have been closed.

These projects and programmes reach a total of 700,000

direct end-users and 6.4 million indirect end-users, the

majority of whom live in rural areas. More than 6,200 people

have participated in training activities. To sustain

development activities involving ICT, IICD and its national

networks supports nine policymaking processes at both the

national and sector level, often with the help of the 10

national and regional ICT for development networks with

which we work.

IICD was established by the Netherlands Ministry of

Foreign Affairs in 1996, and is located in The Hague in the

Netherlands. Our core funders include the Dutch Directorate-

General for Development Cooperation (DGIS) and the Swiss

Agency for Development and Cooperation (SDC).

For more information, please visit www.iicd.org

Online videos on the cases mentioned in this article:

Interview with the President of CRCR (French)

http://www.iicd.org/video/jekafo-gelekan-rural-

information-system-for-farmers-in-the-sikasso-region-pt-3

in the Sikasso region in Mali, farmer cooperatives decided to create a Regional Committee of Rural Consultation (Comité Régional de Concertation des Ruraux, CRCR) to help influence governmental agriculture policy. With support from IICD, CRCR developed a project called Jèkafo Gèlèkan to facilitate access to new laws and market opportunities and to improve communication and knowledge sharing between its members (seven local committees representing 215 farmer organizations). Farmers learned to use the Internet and manage a local radio station to disseminate specific information more widely. Overall, the project reaches about one million farming families that are now more informed and aware of agricultural strategies and policies. CRCR community leaders were able to give feedback on a national law they wished to amend and to consult their members before travelling to Senegal to attend a regional (West-African) meeting on agricultural policies. They have discovered other possibilities
- for ICT uses too, for instance contacting customers in France via email when they hear of strikes to figure out how they can best proceed with exporting their produce.

\section{Conclusions}

OUR EXPERIENGE WITH PROJECTS in Africa and Latin America encourages us to confirm the lasting impact ICT can have on the ground. Although challenges abound, including a lack of political willingness to share information, inadequate infrastructure, skills shortages, and scarce resources, the local impact of the projects that have been implemented so far has a special added value. Incorporating ICT into development projects in diverse thematic areas can generate important changes for disadvantaged communities. These projects have also illustrated that when the focus is on changes and processes, ownership increases.

It has long been said that respecting local cultural frameworks is a pre-condition for the success of any development project. We can now say that this, plus mainstreaming information and communication technologies into projects, is a concrete strategy to promote local empowerment, ownership and effective improvement in knowledge, interactions and associative capacities of the participants involved. With these tools, both Isabel in Inquisivi and the Sikasso farmers are making aid effective and long lasting, even in ways they are unaware of. $\mathrm{c}$

Caroline Figuères, Denise Senmartin and Hilde Eugelink are with the International Institute for Communication and Development (IICD).

\section{Notes}

1 From "Cosechando Nuestros Conocimientos" Booklet and Video. Sergio Quispe, Luis Carlos Aguilar and Napoleon Calcina. Fundación AGRECOL Andes and IICD. Cochabamba, Bolivia, 2008.

2 IICD project summary: http://www.iicd.org/projects/ict-for-the-exchange-offarmer-experiences-in-ecological-agriculture-bolivia/

3 From "Cosechando Nuestros Conocimientos", p. 22. "Using ICT in participatory processes for documentation and exchange has generated, in rural communities, a collective reflexion about natural resources management. Moreover, it has contributed to recovering and strengthening their relations of reciprocity."

4 World Telecommunication/ICT Development Report 2006. Measuring ICT for Social and Economic Development, available at: http://www.itu.int/ ITU-D/ict/publications/wtdr_06/index.html

5 Building Knowledge Economies: Advanced Strategies for Development, summary at:

http://web.worldbank.org/WBSITE/EXTERNAL/WBI/WBIPROGRAMS/ KFDLP/0,,contentMDK:21437029 menuPK:1727232 pagePK:64156158 piPK:64152884 theSitePK:461198,00.html

6 A service hosted and funded by the Development Gateway Foundation and jointly managed with the World Bank, UNDP and OECD. Site: http://aida.developmentgateway.org/index.do

7 Efforts to document these experiences include InfoDev Governance (http://www.infodev.org/en/Topic.5.html), the Commonwealth Centre for e-Governance (http://www.electronicgov.net/about/introletter.shtml), and UNDESA E-Government Survey at

http://unpan1.un.org/intradoc/groups/public/documents/un/unpan028607.pdf among others. 